\title{
Orange Roughy (Hoplosteth us atlanticus Collett 1889) in the Northwest Atlantic
}

\author{
D. W. Kulka \\ Department of Fisheries and Oceans, P. O. Box 5667 \\ St. John's, Newfoundland, Canada A1C 5X1 \\ D. E. Themelis and R. G. Halliday \\ Department of Fisheries and Oceans, Bedford Institute of Oceanography \\ Dartmouth, Nova Scotia, Canada B2Y 4A2
}

\begin{abstract}
New Northwest Atlantic records of Orange roughy (Hoplostethus atlanticus) are reported, consisting of 506 specimens from 219 commercial fishing sets conducted from 1982 to 2000 with bottom otter trawls and gillnets. Percent of observed trawl sets in the study area with orange roughy was $<3$ sets in 1000 observed, lower in other gears, indicating that the species is uncommon there. Most specimens were taken off Baffin Island at $63^{\circ} \mathrm{N}$. The others were from the Northeast Newfoundland and Labrador Shelf, Grand Banks, Flemish Cap, Scotian Shelf and the Corner Seamounts south of the Grand Banks at about $35^{\circ} \mathrm{N}$. Virtually all captures were at $285-1330 \mathrm{~m}$ and predominantly deeper than $800 \mathrm{~m}$. The only exception was a record of four specimens at $70 \mathrm{~m}$ but the specimens were not available to the authors for verification. Average long-term bottom temperatures where captures occurred were $2-9^{\circ} \mathrm{C}$, but primarily from 3 to $4^{\circ} \mathrm{C}$. A sample of 27 specimens was examined in detail and, based on these, data on meristics and morphometrics, size composition, reproductive stages and food composition are provided. It is not possible, based on present data, to establish whether the species reproduces in the Northwest Atlantic. However, water temperatures in the north, where most specimens were caught, are not conducive to survival of orange roughy eggs and larvae. A possible hypothesis is that the Northwest Atlantic occurrences represent the western fringe of distribution of Northeast Atlantic populations.
\end{abstract}

Key words: distribution, biology, Hoplostethus, orange roughy

\section{Introduction}

Orange roughy (Hoplostethus atlanticus, Collett 1889, Trachichthyidae) is a widely distributed deepwater species found along the continental slopes and on seamounts of the Atlantic, Indian and Pacific oceans. Although first recorded in the North Atlantic off the Azores, orange roughy was initially exploited in the South Pacific. In the late-1970s and in the 1980s, fisheries were developed off New Zealand and subsequently off southern Australia. In the 1990s, fishing started in the southern Indian Ocean, off Namibia and Chile and in the Northeast Atlantic (Branch, 2001). According to Branch (2001), the species occurs at 450-1 $800 \mathrm{~m}$ but commercial fisheries are conducted over a narrower depth range of 600-1 $400 \mathrm{~m}$, highest catches being recorded where temperatures are $4.5-6.5^{\circ} \mathrm{C}$.

In the Northeast Atlantic, orange roughy have been found along the slope to the west of the British
Isles (Bridger, 1978; Ehrich, 1983; Mauchline and Gordon, 1984; Merrett and Wheeler, 1983; Pechenik and Troyanovskii, 1970), off the Faroe Islands and on Hatton Bank to the southwest (Thomsen, MS 1998), off the south coast of Iceland (Magnússon and Magnússon, 1995) and along the Mid-Atlantic Ridge to the Azores (Hareide and Garnes, 2001, Magnússon and Magnússon, 1995; Thomsen, MS 1998). Commercial catches have been taken in all of these areas, but quantities to date have been small compared to those from New Zealand and Australian waters (ICES, MS 1995, MS 1996).

The first published records of orange roughy catches in the Northwest Atlantic (defined here as west of $42^{\circ} \mathrm{W}$, the boundary line between the ICES and NAFO areas) are provided by Pechenik and Troyanovskii (1970) who reported "a few dozen specimens" caught in April 1964 during USSR exploratory fishing off West Greenland at 620-680 m 
and some single specimens taken in later years. Woods and Sonoda (1973) subsequently recorded 14 specimens as being caught by a U.S. fishing vessel in 1960 in the Gulf of Maine (but see below). More recently, Vinnichenko (1997) listed orange roughy as being caught on the Corner Seamounts south of the Grand Banks during investigations by the USSR and the Russian Federation in 1976-96, but quantities are not given.

The present paper provides new records of orange roughy from the continental slope off Canada and from the Corner Seamounts. Species distribution is described in relation to depth and bottom temperature and some biological information is provided. The status of the species in the Northwest Atlantic and its potential to support commercial fishing are discussed.

\section{Methods}

Most of our records of orange roughy were obtained through the Canadian Department of Fisheries and Oceans (DFO) at-sea Fishery Observer Program (Kulka and Firth, 1987) from observations made aboard vessels of all countries fishing in waters off Canada. A number of reports of orange roughy captures, photographs and confirming specimens were obtained from fishery observers in the $1980 \mathrm{~s}$. Consequently, systematic collection procedures were introduced in 1991. The fishery observers were provided with identification kits, including colour photographs of orange roughy and were instructed to record all catches and to return specimens to DFO whenever feasible. Between 1991 and 2000, about 203 000 commercial fishing sets were observed. A few additional specimens were obtained directly from fishing companies or individual fishermen. Examination of all catch records from extensive research vessel bottom trawling surveys (1951-2001) conducted by DFO from Labrador to Georges Bank and from commercial fishing statistics yielded no records of orange roughy.

Average bottom water temperatures were calculated for the area from Davis Strait to the Gulf of Maine from the Marine Environmental Data Service (MEDS, the Canadian national and NAFO regional oceanographic data centre, DFO, Ottawa) database for 1972-2000. The MEDS data were based on bottom temperature readings obtained from various sources including spring, summer and autumn surveys carried out by DFO. These long-term average temperatures were associated with catch records using the geographic information system SPANS (Anon, 1997).
A total of 27 specimens were obtained by the authors for detailed examination, taken from throughout the geographic range of present records. These specimens were measured for 11 morphometric characteristics and 16 meristic counts according to Woods and Sonoda (1973) and Merrett and Wheeler (1983). Reproductive state was observed for 24 specimens (14 females, 10 males) using the criteria of Du Buit (1995) and Thomsen (MS 1998) as guidance. Stomach contents were examined for 18 specimens.

\section{Results}

New records of orange roughy consisting of 506 specimens from 219 commercial fishing sets made in 1982-2000 are reported for the Northwest Atlantic. Meristic and morphometric characters of 27 fish from the full geographic range of the present collection confirmed that all were $H$. atlanticus. All counts and measurements of our specimens fell within the ranges listed by Woods and Sonoda (1973), Paulin (1979) and Kotlyar (1980) in Atlantic, Pacific and Indian Oceans (Table 1).

\section{Distribution}

Of the 506 orange roughy recorded, 498 came from the continental slope off Canada and eight from

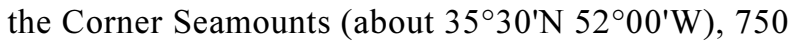
$\mathrm{km}$ south of the Grand Bank. Along the Northwest Atlantic slope, orange roughy were recorded as far north as $64^{\circ} 34^{\prime} \mathrm{N}$ in Davis Strait and as far southwest as $42^{\circ} 38^{\prime} \mathrm{N} 63^{\circ} 30^{\prime} \mathrm{W}$, south of Nova Scotia (Fig. 1). Most records (175 sets yielding 436 individuals) are in two clusters in the north, centered at $63^{\circ} \mathrm{N}$ (Fig. 1). Further south, records were fewer and more dispersed: 44 individuals from the northeast Newfoundland Shelf and Grand Banks, 14 from the Flemish Cap and 4 from the Scotian Shelf. Most catches were of 1-2 individuals and in only three cases was the catch greater than five specimens. Two of the most northern catches were of 10 individuals and eight fish were taken in a set to the southeast of St. Pierre Bank (Fig. 1).

Orange roughy were taken with bottom gears, mainly as by-catch in Greenland halibut, shrimp (slope waters off Canada) and alfonsino (Corner Seamount) trawl fisheries. A few specimens were taken with gillnets but none were recorded from longlines. Frequency of occurrence was greatest in the demersal trawl fishery but even in this case the species occurred in $<3$ sets in 1000 observed. Orange roughy occurred in a greater proportion of sets $(0.66 \%)$ north of $55^{\circ} \mathrm{N}$ 
TABLE 1. Meristic counts and morphometric measurements for H. atlanticus in the present study and comparisons with previous studies. (Morphometric measurements are given as \% standard length).

\begin{tabular}{lcccc}
\hline \hline & $\begin{array}{c}\text { Northwest } \\
\text { Atlantic } \\
\text { (present study) }\end{array}$ & $\begin{array}{c}\text { Northwest } \\
\text { Atlantic (Woods } \\
\text { and Sonoda 1973) }\end{array}$ & $\begin{array}{c}\text { Pacific } \\
\text { Ocean } \\
\text { (Paulin 1979) }\end{array}$ & $\begin{array}{c}\text { Atlantic, Pacific, } \\
\text { Indian Ocean } \\
\text { (Kotlyar 1980) }\end{array}$ \\
\hline Number of fish & 27 & 18 & 12 & 25 \\
Standard length range (mm) & $295-510$ & $390-492$ & $192-395$ & $86-430$ \\
Dorsal fin rays & VI-VII 15-16 & V-VI, 15-18 & VI 15-18 & V-VI 15-18 \\
Anal fin rays & III 10-11 & III 10-11 & III 10-11 & II-III 10-12 \\
Pectoral fin rays & $15-20$ & $17-20$ & $18-20$ & $16-20$ \\
Pelvic fin rays & I 6 & I 6 & I 6 & 6 \\
Caudal fin rays & $30-36$ & $29-31$ & & $17-22$ \\
Branchiostegal rays & 8 & 8 & $19-21$ & $29-33$ \\
Gill rakers & $18-22$ & $20-22$ & $31-34$ & $29-30$ \\
Lateral line scales & $28-32$ & $29-32$ & 28 & $13-20$ \\
Total vertebrae & $28-29$ & 29 & $19-25$ & $8.9-9.8$ \\
Scutes in abdominal keel & $13-21$ & $13-20$ & $11.4-12.9$ & $8.2-9.8$ \\
Snout length & $8.0-10.9$ & $9.1-10.5$ & & $6.5-11.2$ \\
Interorbital distance & $11.0-13.6$ & $10.9-13.0$ & $33.7-39.1$ & $26.2-39.8$ \\
Eye orbit diameter & $7.4-10.1$ & $8.21-9.56$ & $38.5-45.6$ & $32.5-47.6$ \\
Upper jaw length & $20.2-25.1$ & $20.1-23.2$ & &
\end{tabular}

${ }^{1} \mathrm{~N}=25$

${ }^{2} \mathrm{~N}=26$

than to the south $(0.03 \%)$ indicating that the larger number of records in the north is not just a function of greater fishing effort. When the groundfish trawl data are standardized to fishing sets in depths $>500$ $\mathrm{m}$ (in which most orange roughy were caught), northern sets yielded orange roughy about five times more frequently than did those in the south. Captures in other gears were too low to draw conclusions about relative abundance by area.

The range of bottom depths at which orange roughy were caught (with one exception) was 285-1 $330 \mathrm{~m}$, with $80 \%$ taken from greater than $900 \mathrm{~m}$. The exception was four specimens from one set at $70 \mathrm{~m}$ in the yellowtail flounder fishery on southwestern Grand Bank. (See Conclusions for a discussion of the validity of this record.) In the north, despite a substantial amount of fishing effort being expended shallower than $700 \mathrm{~m}$ (the majority of sets), almost no orange roughy were caught at those shallower depths (Fig. 2). Number caught per 1000 sets fished increased steadily from near zero at $701-800 \mathrm{~m}$ to 33 fish at $1200+\mathrm{m}$. South of $55^{\circ} \mathrm{N}$ the catch rate did not show a clearly increasing trend with depth and records were more frequent at depths $<700 \mathrm{~m}$ than in the north (Fig. 2). The variability in catch rates with depth in the south is probably in part a result of the lower catch rate of orange roughy and perhaps partly a result of the much lower fishing effort that has occurred in deep water in this area.

There are no temperature observations directly associated with our orange roughy records. However, an overlay of records on a long-term bottom temperature surface derived from MEDS data show that the locations where most orange roughy occur was where average bottom temperatures range between 3 and $4^{\circ} \mathrm{C}$ (Fig. 3). Nineteen percent of the records were from locations that had average temperatures of $2-3^{\circ} \mathrm{C}$, all except one of which occurred north of $55^{\circ} \mathrm{N}$. In the south, records occur in locations with temperatures from $2.5^{\circ}$ to as high as $9^{\circ} \mathrm{C}$. The majority of occurrences where average bottom temperature exceeded $4^{\circ} \mathrm{C}$ were associated with shallow sets (less than $700 \mathrm{~m}$ ). The cumulative probability plot (Fig. 3, lower panel) demonstrates that orange roughy are proportionately under-represented in terms of available area at temperatures less than $3.5^{\circ} \mathrm{C}$. 


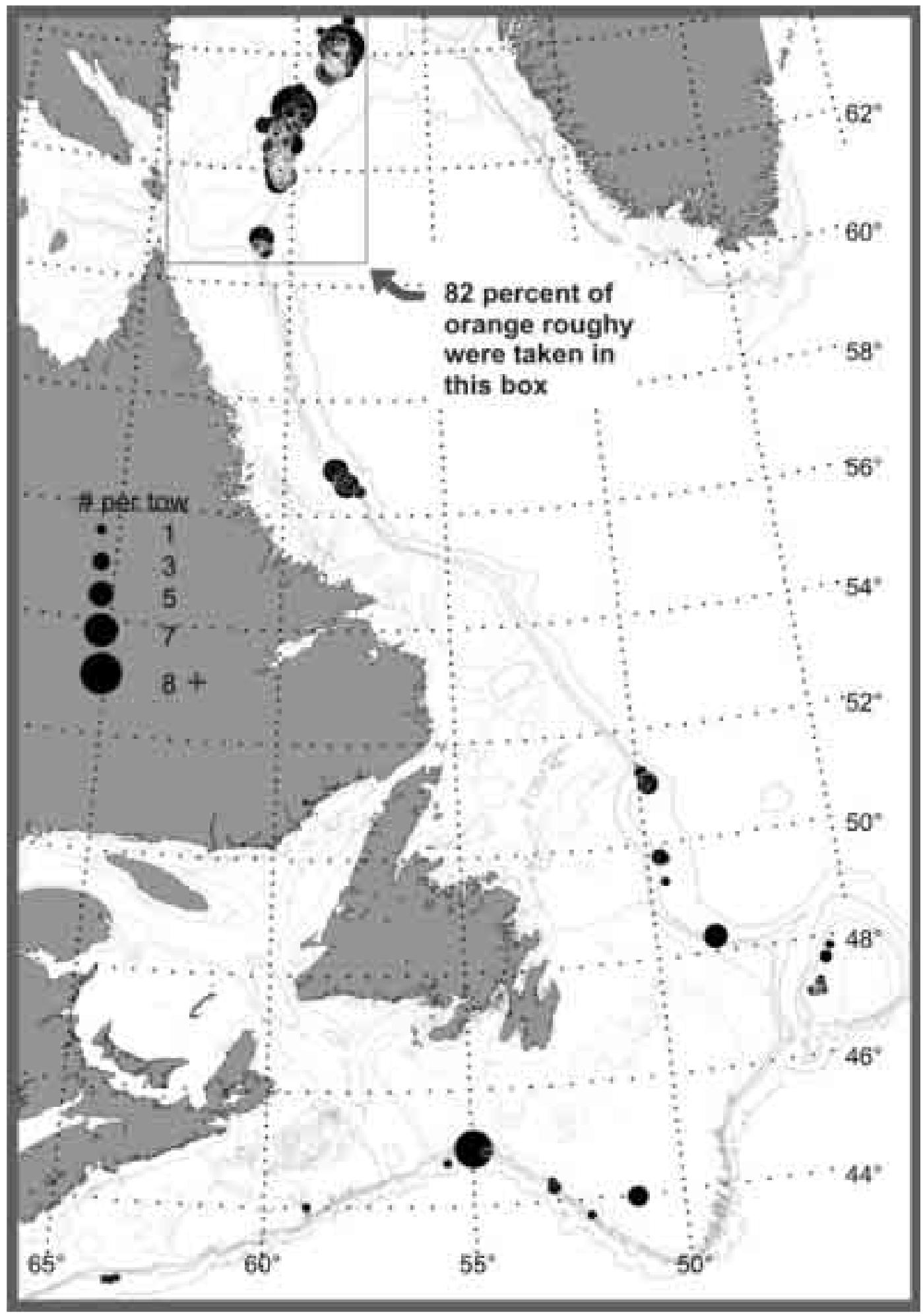

Fig. 1. Distribution of present records of orange roughy. Eight records from Corner Seamounts (approx. $\left.35^{\circ} 30^{\prime} \mathrm{N} 52^{\circ} 00^{\prime} \mathrm{W}\right)$ not shown. Depths contours depicted range from $250 \mathrm{~m}$ to $2000 \mathrm{~m}$. 

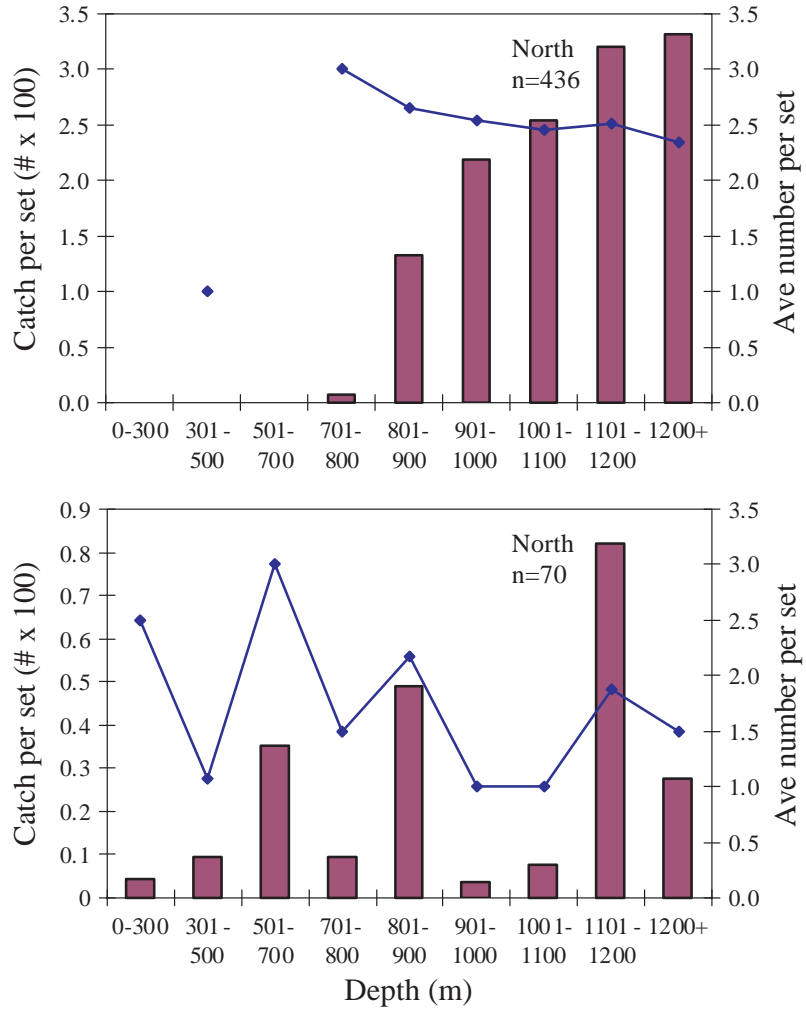

Fig. 2. Number of orange roughy per 1000 sets fished (bars) and number of orange roughy caught per successful set (lines), by depth range (otter trawl data only). Top panel - north of Lat. $55^{\circ} \mathrm{N}$, lower panel - south of Lat. $55^{\circ} \mathrm{N}$.

Temperatures at the depths important to this study are stable seasonally but could still be subject to longer-term trends, and thus the results of this analysis cannot be taken as establishing that orange roughy actually occurred at temperatures as low as $2^{\circ} \mathrm{C}$. No temperature data were available for the Corner Seamounts, requiring that these records be left out of this analysis.

\section{Length Conversion Factors}

The following equations describe the relationships between standard length (SL) and fork length (FL) and total length (TL) within the range of SL of the 27 specimens examined in detail $(295-510 \mathrm{~mm})$ when length is in mm:

$$
\begin{aligned}
& \mathrm{SL}=0.907 \mathrm{FL}-2.019 \quad\left(\mathrm{n}=25 ; \mathrm{r}^{2}=0.98\right) \\
& \mathrm{SL}=0.813 \mathrm{TL}-1.935 \quad\left(\mathrm{n}=18 ; \mathrm{r}^{2}=0.98\right) \\
& \mathrm{FL}=0.867 \mathrm{TL}+17.21 \quad\left(\mathrm{n}=18 ; \mathrm{r}^{2}=0.97\right)
\end{aligned}
$$

\section{Length-Weight Relationships}

Length-weight relationships, with length in $\mathrm{mm}$ and weight (W) in $g$ were calculated as:

$$
\begin{array}{ll}
\mathrm{W}=0.000413 \mathrm{SL}^{2.585} & \left(\mathrm{n}=27 ; \mathrm{r}^{2}=0.93\right) \\
\mathrm{W}=0.000189 \mathrm{FL}^{2.671} & \left(\mathrm{n}=25 ; \mathrm{r}^{2}=0.95\right) \\
\mathrm{W}=0.000145 \mathrm{TL}^{2.664} & \left(\mathrm{n}=18 ; \mathrm{r}^{2}=0.94\right)
\end{array}
$$

The fish were frozen for varying lengths of time prior to thawing and weight determination and this is likely to have introduced some differences in weights from the fresh condition (Halliday and Roscoe, 1969).

\section{Length Composition}

The length range of orange roughy in the detailed sample of 27 fish was 365--630 mm TL (295-510 mm $\mathrm{SL}$ ), average $546 \mathrm{~mm}$ TL. There was a suggestion of bimodality in the length frequency (Fig. 4) with one group of fish in the $350-450 \mathrm{~mm}$ range and another in the $500-650 \mathrm{~mm}$ range. It is not likely that the length distribution of the few fish measured represents the entire catch of 506 fish but it does show that a fairly broad size range of fish were caught. Fish belonging to both the small and large size groups were caught off Baffin Island, off Labrador and east Newfoundland and on the Scotian Shelf slope, i.e. throughout the range of our records.

\section{Reproduction}

Reproductive state was observed for 24 specimens (14 females, 10 males), 19 of which were caught in August to November. Three of the smallest females, 370-480 mm TL (295-385 mm SL) contained ovaries that were translucent and pink in colour, firm and regular in shape and about $30 \%$ as wide as long. Two other females in this size range had ovaries that differed only in having walls that were opaque and less pink. In contrast, the nine larger females, 520$630 \mathrm{~mm}$ TL (420-510 mm SL) had ovaries that were relatively larger, purplish and flaccid or, if firm, beige in colour and were, on average, about half as wide as long. Of the males, 510-620 mm TL (410-500 mm SL), eight had fairly large and firm, cream coloured testes that were about half as wide as long in six cases but only about one third as wide as long in two fish of 520 and $560 \mathrm{~mm}$ TL (420 and $455 \mathrm{~mm} \mathrm{SL}$ ). The remaining two males had irregular shaped, laterally shrunken testes. Most testes had black spots on their surface, which were extensive in some cases.

All females over $480 \mathrm{~cm}$ TL $(385 \mathrm{~cm} \mathrm{SL})$ were deemed mature while three and possibly all five, of the females of this size and smaller may have been immature. One female, caught off the Scotian Shelf in July was clearly at a ripening stage, whereas most of the large females appeared to be spent or recovering, 

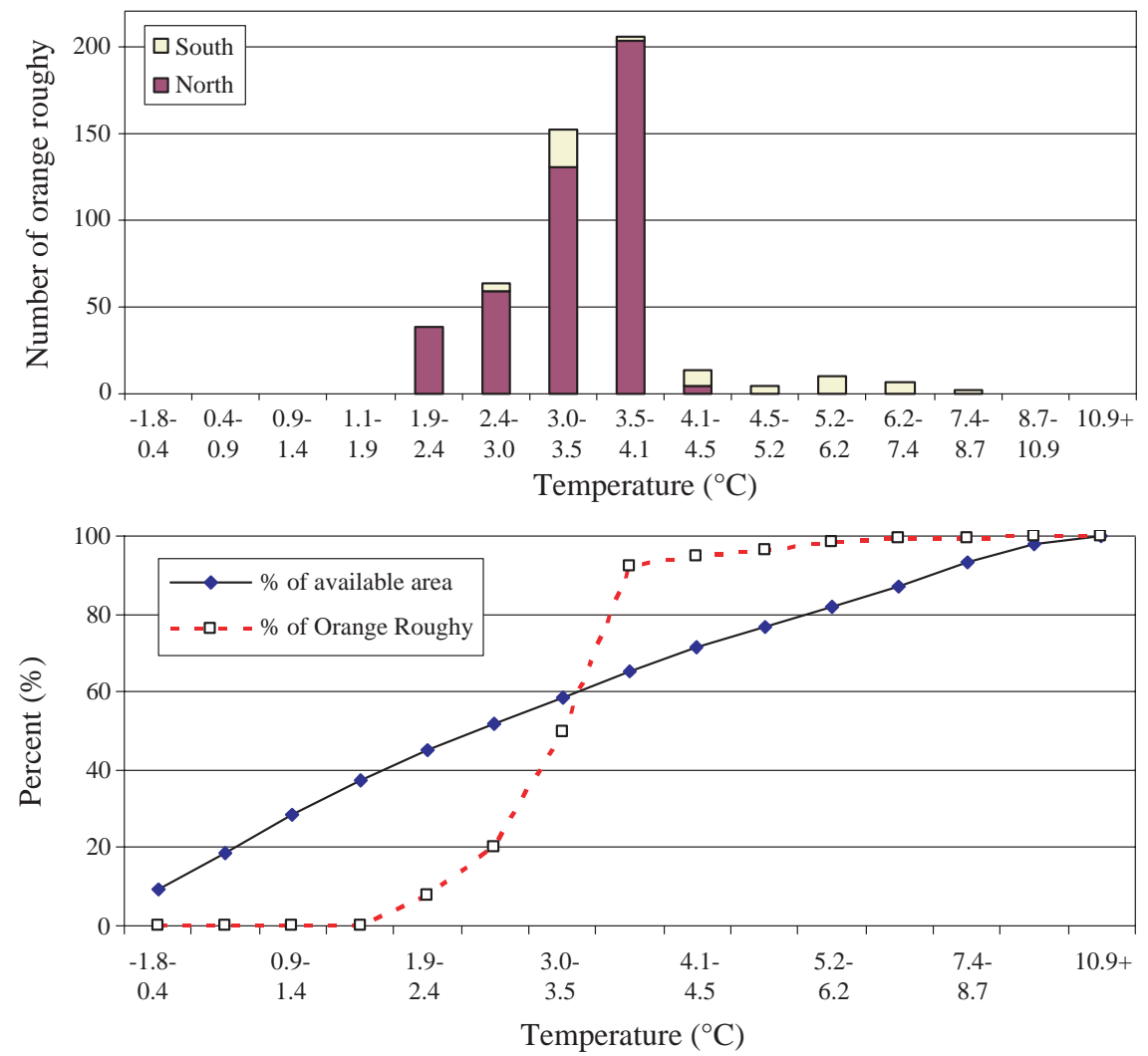

Fig. 3. Number of orange roughy caught (upper panel) and percent of orange roughy taken within each temperature category compared to percent of available area. The bottom temperatures are long-term means, 1972-2000 obtained from MEDS records.

although some of these contained eggs large enough to be seen by the naked eye. All males, with the possible exception of the two fish with testes one third as wide as long, were mature. Several, taken in October-November, appeared to be ripening.

\section{Food}

Of 18 stomachs examined, five were empty. Seven contained creamy or liquified white or yellow tissue, unrecognizable as to taxon. The remaining six fish contained shrimps recognisable as sergestids in two instances and in a further two as pasiphaeids. One specimen was identifiable as Pasiphaea tarda. Two stomachs also contained fish, one of which was a 20 $\mathrm{cm}$ specimen of the notosudid, Scopelosaurus lepidus. One stomach contained two cephalopod beaks.

\section{Discussion}

Three other trachichthyid species, Gepheroberyx darwini, Hoplostethus mediterraneus and Hoplo- stethus occidentalis, have been recorded from the Gulf of Maine area, adjacent to the southern limit of our records of $H$. atlanticus (Moore, 2002; Van Guelpen,

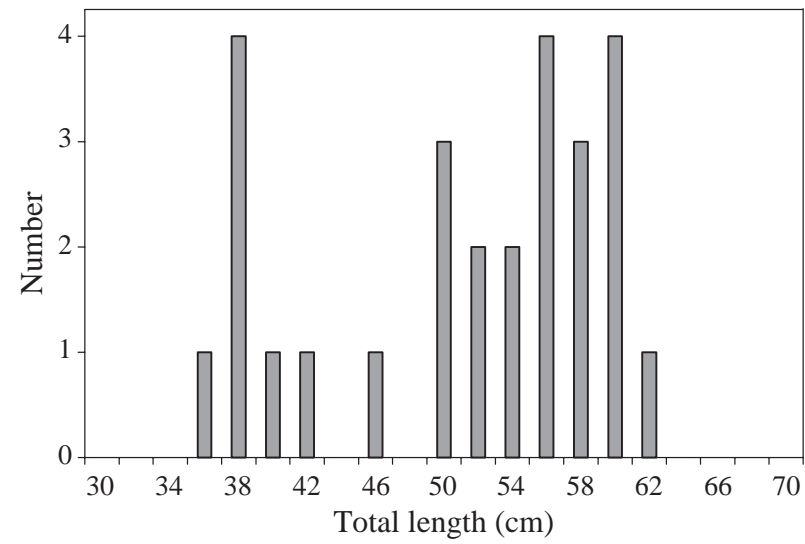

Fig. 4. Length frequency of Northwest Atlantic orange roughy. (2 cm groupings: $30 \mathrm{~cm}$ includes all fish from 30.0 to $31.9 \mathrm{~cm}$, etc.) 
1993). Also, Vinnichenko (1997) recorded H. mediterraneus as more abundant than $H$. atlanticus on the Corner Seamounts. Our H. atlanticus were distinguishable from $H$. mediterraneus and $H$. occidentalis by higher dorsal jointed ray counts (15-18 vs 10-13 in H. mediterraneus and 10-14 in $H$. occidentalis) and smaller eye to standard length ratios (7.4-10.1 vs 13.5-16.1 in H. mediterraneus and 11.6-14.7 in H. occidentalis) (Moore, 2002). Although one of our specimens $(295 \mathrm{~mm}$ standard length), caught off Labrador, had a patch of vomerine teeth characteristic of $G$. darwini (Merrett and Wheeler, 1983), it corresponded with $H$. atlanticus in all other features. All four of our most southern records, from the Scotian Shelf where confusion with the other, more southerly distributed, species would be most likely, were among the 27 specimens examined in detail. Thus, although all records were not confirmed by us, we believe that all the specimens we recorded were $H$. atlanticus.

This study establishes that orange roughy is widespread and persistent in the Northwest Atlantic. Frequency of occurrence was low throughout the area but higher off southern Baffin Island at the entrance to Davis Strait between $61^{\circ} \mathrm{N}$ and $65^{\circ} \mathrm{N}$. Extensive trawl effort north of $65^{\circ} \mathrm{N}$ (38 000 sets in 400-1 500 $\mathrm{m})$ yielded no orange roughy and thus we have defined its northern limit in the Northwest Atlantic. We believe also that our Scotian Shelf records are the most southerly on the continental slope despite the records of Woods and Sonoda (1973). The latitude and longitude given by Woods and Sonoda for their collection $\left(44^{\circ} 40^{\prime} \mathrm{N} 56^{\circ} 59^{\prime} \mathrm{W}\right)$ gives a location of origin in the Laurentian Channel, not in the Gulf of Maine as stated. It seems more likely that the geographic co-ordinates are correct and that the location name reflects that of the port of origin of the catching vessel (Moore, 2002). Our records also confirm the presence of orange roughy on the Corner Seamounts, first noted by Vinnichenko (1997).

Species depth distribution is given by Branch (2001) as 450-1 $800 \mathrm{~m}$ and, indeed, all Northeast Atlantic records lie within this range (ICES, MS 1995; Hareide and Garnes, 2001; Magnússon and Magnússon, 1995; Merrett and Wheeler, 1983) except for a catch record by Gordon and Duncan (1987) at $1908 \mathrm{~m}$. Highest density is recorded as occurring at $800-1300 \mathrm{~m}$ in the Northeast Atlantic and present records suggest that the same is true in the Northwest Atlantic. The deepest of present records was at $1330 \mathrm{~m}$ even though, north of the Scotian Shelf, where all but four of the specimens were caught, fishing occurred regularly to $1500 \mathrm{~m}$ and occasionally to $1700 \mathrm{~m}$. However, the upper depth limit of present records is noteworthy. Nineteen specimens were taken in 15 sets shallower than $450 \mathrm{~m}$. All but two cases occurred in the Flemish Cap shrimp fishery in 300-350 m, these exceptions being in the flatfish fisheries on Grand Bank at 70 and $285 \mathrm{~m}$. A depth of $70 \mathrm{~m}$ is much shallower than this species has been previously recorded. Identification of the four specimens recorded at this location was by an observer trained to recognize orange roughy and no other species that resemble orange roughy occur at this depth. However, none of the four specimens was returned to the lab for verification and although no reason can be found to reject the record, it must be considered uncertain.

There is little information on the preferred temperature range of orange roughy. Branch (2001) notes that most large catches are recorded at $4.5-6.5^{\circ} \mathrm{C}$ and gives a species range off Namibia of $3-9^{\circ} \mathrm{C}$. Hareide and Garnes (2001) made catches on the MidAtlantic Ridge at $5.0-10.2^{\circ} \mathrm{C}$. Ehrich (1983) reports catches at a temperature as high as $9^{\circ} \mathrm{C}$ west of the British Isles but concludes that preferred temperatures are $7.5^{\circ} \mathrm{C}$ and lower. Present data suggest a range of at least $2.4-8.7^{\circ} \mathrm{C}$ with most occurring at $3-4^{\circ} \mathrm{C}$. Available habitat along the slope, in terms of bottom temperature with respect to depth, may explain the observed orange roughy distribution pattern. Along the slope off Canada, bottom water of $3^{\circ} \mathrm{C}$ and higher does not occur at $1000 \mathrm{~m}$ or shallower along much of the Labrador Shelf to eastern Grand Bank slopes and it is in these areas that orange roughy are not recorded. Two exceptions are an area of warm $\left(>3^{\circ} \mathrm{C}\right)$ bottom water on the slope just north of $56^{\circ} \mathrm{N}$ and at this location 19 orange roughy were taken and the Flemish Cap where the 13 shallow sets yielding orange roughy noted above were associated with warm temperatures $\left(4.1-5.2^{\circ} \mathrm{C}\right)$.

The length-weight relationships for our fish are similar to those reported from west of Britain (Gordon and Duncan, 1987; ICES, MS 1996) and off Faroes, Iceland and on the Mid-Atlantic Ridge (Magnússon and Magnússon, 1995; Thomsen, MS 1998). A fish measuring $40 \mathrm{~cm} \mathrm{SL}$, i.e. about $50 \mathrm{~cm} \mathrm{TL}$, weighed $2.2 \mathrm{~kg}$ in the Northwest Atlantic and $2.0-2.3 \mathrm{~kg}$ in the Northeast Atlantic, depending on the regression used. Length conversion factors are also essentially the same as obtained from west of Britain (ICES, MS 1996) and off Iceland (Magnússon and Magnússon, 1995). 
Lengths (TL) of orange roughy in exploratory fishing or commercial catches in the Northeast Atlantic have a mode between 50 and $65 \mathrm{~cm}$ or slightly larger, in a few cases up to $70 \mathrm{~cm}$, and on the MidAtlantic Ridge and south of Iceland only fish of these sizes have been caught (ICES, MS 1995, MS 1996; Magnússon and Magnússon, 1995, Thomsen, MS 1998). However, French catches along the European continental slope also contain smaller fish with a mode between 30 and $45 \mathrm{~cm}$ (ICES, MS 1995, MS 1996) and Thomsen (MS 1998) notes some fish in the 30$35 \mathrm{~cm}$ range off Faroe. In contrast, research vessel survey catches west of the British Isles caught only fish in the $15-45 \mathrm{~cm}$ range with indications of modality at $15-25 \mathrm{~cm}$ and $30-45 \mathrm{~cm}$ (Gordon and Duncan, 1987). The length composition of our Northwest Atlantic data spans the modes in length frequency at $30-45 \mathrm{~cm}$ and $50-65 \mathrm{~cm}$ observed in commercial catches from European waters. The 14 specimens of Woods and Sonoda (1973) from the Northwest Atlantic were in the range $48-61 \mathrm{~cm} \mathrm{TL}$, consistent with the larger of these modes.

The spawning period in the Northeast Atlantic is in late January to early March (Du Buit, 1995; Thomsen, MS 1998) and a similar timing could be expected in the Northwest Atlantic. As almost all of the present specimens were collected in AugustNovember, few, if any instances of the later stages of maturity would be expected to occur. Our specimens showed signs of reproductive development but appeared to be mainly in early ripening or spent/ recovering stages. However, ripening does not necessarily lead to spawning. Bell et al. (1992) found a high proportion of adult female orange roughy off southeastern Australia either did not develop or initiated egg production but subsequently resorbed the developing eggs. Specimens collected in the JanuaryMarch period are required to establish definitively that spawning is occurring in the Northwest Atlantic.

West of Britain, orange roughy have a size at first maturity of about $51 \mathrm{~cm}$ TL (41 cm SL) (Du Buit, 1995; Gordon and Duncan, 1987). Thomsen (MS 1998), who sampled more widely, including along the Mid-Atlantic Ridge, found a size at first maturity of about $44-45 \mathrm{~cm}$ TL (36 cm SL) and of $50 \%$ maturity of 48-49 $\mathrm{cm}$ TL $(39-40 \mathrm{~cm} \mathrm{SL})$. Thus, the interpretation given to present data that some females $<48 \mathrm{~cm}$ TL were likely immature, whereas most if not all $>48 \mathrm{~cm}$ were mature is consistent with the relationship of maturity to length in the Northeast Atlantic.
Although few stomachs were examined, they indicated that diet in the Northwest Atlantic is similar to that in the Northeast Atlantic (Magnússon and Magnússon, 1995; Mauchline and Gordon, 1984; Thomsen, MS 1998) and elsewhere (Bulman and Koslow, 1992; Kotlyar and Lipskaya, 1981; Rosecchi et al., 1988) in its dependence on benthopelagic decapod crustaceans, fish and cephalopods.

\section{Conclusion}

Present records do not fully define the status of orange roughy in the Northwest Atlantic. It is of persistent occurrence along much of the continental slope off Canada, the size range of the specimens caught is comparable to those taken off the Northeast Atlantic continental slope and the Northwest Atlantic fish show signs of reproductive activity. Thus, the possibility of there being populations indigenous to the Northwest Atlantic cannot be discounted. However, the failure to locate concentrations of any size despite extensive sampling at appropriate depths (at least north of $55^{\circ} \mathrm{N}$ ) argues against this, and evidence of gonadal development is not a sufficient basis to conclude that the species is reproducing successfully in the area. As well, orange roughy eggs require water temperatures $>6^{\circ} \mathrm{C}$ to successfully complete development (Zeldis et al., 1995). In the study area, temperatures this high in January-March, the likely spawning period, occur in the water column over the deep slope waters occupied by orange roughy only to the south and west of Flemish Cap (Drinkwater and Trites, 1986, 1987). This is a further arguement against reproductive success, at least in the Davis Strait to northeastern Grand Banks area.

The concentration of present catch records at the mouth of Davis Strait and the highest rate of occurrence there suggests that the Northwest Atlantic captures may represent the western fringe of distribution of Northeast Atlantic populations. There is nothing in the literature to support hypotheses of dispersion as adults over deep ocean depths, or through drift at egg and larval stages. Eggs and larvae only spend about 10 days in the water column (Bulman and Koslow, 1995; Zeldis et al., 1995), a strategy more consistent with retention of progeny (Zeldis et al., 1995) rather that their long-distance dispersal. More likely is a dispersion at the juvenile and adult phases from Iceland along the southern slope of the IcelandGreenland Ridge to western Greenland where the species has been recorded by Pechenik and Troyanovskii (1970) and by this study. There are as 
yet no published records from the intervening area off East Greenland and a number of deep water trawl surveys off both West and East Greenland in recent years did not capture any orange roughy off the east coast of Greenland although several specimens were taken off West Greenland (O. A. Jørgensen, Danish Institute for Fisheries Research, Charlottenlund Slot, 2920 Charlottenlund, Denmark; pers. comm.). Thus, the closest records east of the Davis Strait are those of Magnússon and Magnússon (1995) off southwestern Iceland. However, temperatures at $1000 \mathrm{~m}$ along the southern slope of the Greenland-Iceland ridge and off East Greenland are on average above $3^{\circ} \mathrm{C}$, comparable to those off West Greenland and southern Baffin Island (M. Stein, Institut für Seefischerei, D-22767 Hamburg, Germany; pers. comm.). Thus, temperature would not appear to present a barrier to dispersion from east to west via East Greenland.

Finding commercial quantites of orange roughy in the Northwest Atlantic, an interest expressed by the fishing industry, is contingent on there being reproducing and dense populations in the area. Environmental conditions argue agaist reproductive success at least north of the Grand Banks. Along most of the slope of the Labrador and Northeast Newfoundland Shelf, there has been sufficient commercial fishing effort at suitable depths to give an indication of the possibility of developing a directed orange roughy fishery. The results suggest that the likelihood is remote. In contrast, in more southern areas, where temperatures are more suitable for orange roughy, the deeper slope has been far less extensively explored and prospects for commercial exploitation, although unlikely, cannot be so categorically ruled out.

\section{Acknowledgments}

We thank the fishery observers, fishing companies and others who have brought to our attention records and specimens of orange roughy. We are grateful to Jon A. Moore, Florida Atlantic University, USA, and also Karsten Hartel of the Museum of Comparative Zoology, Harvard, for informing us of the results of their investigations on the origin of the specimens reported in Woods and Sonoda (1973). We are grateful also to Manfred Stein, Sea Fisheries Institute, Hamburg, for information on water temperatures off East Greenland and on the Greenland-Iceland Ridge and to Ole Jørgensen, Danish Institute for Fisheries Research, for information on orange roughy records off Greenland.

\section{References}

ANON. 1997. SPANS. Ver. 7 Spatial analysis system. Reference Manual. Tydac Research Inc. $3^{\text {rd }}$ Edition.

BELL, J. D., J. M. LYLE, C. M. BULMAN, K. J. GRAHAM, G. M. NEWTON and D. C. SMITH. 1992. Spatial variation in reproduction, and occurrence of nonreproductive adults, in orange roughy, Hoplostethus atlanticus Collett (Trachichthyidae), from southeastern Australia. J. Fish Biol., 40: 107-122.

BRANCH, T. A. 2001. A review of orange roughy Hoplostethus atlanticus fisheries, estimation methods, biology and stock structure. South African J. Mar. Sci., 23: 181-203.

BRIDGER, J. P. 1978. New deep-water trawling grounds to the west of Britain. Laboratory Leaflet, Directorate of Fisheries Research, Ministry of Agriculture, Fisheries and Food, Lowestoft. 40 p.

BULMAN, C. M. and J. A. KOSLOW. 1992. Diet and food consumption of a deep-sea fish, orange roughy Hoplostethus atlanticus (Pisces: Trachichthyidae), from southeastern Australian waters. Mar. Ecol. Prog. Ser., 82: $115-129$.

BULMAN, C. M. and J. A. KOSLOW. 1995. Development and depth distribution of the eggs of orange roughy, Hoplostethus atlanticus (Pisces: Trachichthyidae). Mar. Freshwat. Res. ,46: 697-705.

DRINKWATER, K. F. and R. W. TRITES. 1986. Monthly means of temperature and salinity in the Grand Banks region. Can. Tech. Rep. Fish. Aquat. Sci., 1450: 115 p.

DRINKWATER, K. F. and R. W. TRITES. 1987. Monthly means of temperature and salinity in the Scotian Shelf region. Can. Tech. Rep. Fish. Aquat. Sci., 1539: 104 p.

DU BUIT, M.-H. 1995. Notes préliminaires sur la ponte de l'hoplostèthe (Hoplostethus atlanticus, Trachichthyidae) a l'ouest des Iles Britanniques. Cybium 19(2): 199-200.

EHRICH, S. 1983. On the occurrence of some fish species at the slopes of the Rockall Trough. Arch. FischWiss. 33: $105-150$.

GORDON, J. D. M. and J. A. R. DUNCAN. 1987. Aspects of the biology of Hoplostethus atlanticus and H. mediterraneus (Pisces: Berycomorphi) from the slopes of the Rockall Trough and the Porcupine Sea Bight (northeastern Atlantic). J. mar. biol. Ass. U.K. 67: 119-133.

HALLIDAY, R. G. and B. ROSCOE. 1969. The effects of icing and freezing on the length and weight of groundfish species. ICNAF Redbook 1969, Part III, Selected Papers, p. 79-89.

HAREIDE, N.-R. and G. GARNES. 2001. The distribution and catch rates of deep water fish along the Mid-Atlantic Ridge from 43 to $61^{\circ}$ N. Fish. Res., 51: 297-310.

ICES MS 1995. Report of the study group on the biology and assessment of deep-sea fisheries resources. ICES C.M. Doc., No. Assess: 4, Ref.: G, 91 p.

MS 1996. Report of the study group on the biology and assessment of deep-sea fisheries resources. ICES C.M. Doc., No. Assess: 8: 145 p. 
KOTLYAR, A. N. 1980. Systematics and distribution of trachichthyid fishes (Trachichthyidae, Beryciformes) of the Indian Ocean. Trudy Inst. Okeanol. 110: 177-224.

KOTLYAR, A. N. and N. Y. LIPSKAYA. 1981. Feeding of Hoplostethus atlanticus Collett (Trachichthyidae, Beryciformes). In: Fishes of the Open Ocean. Institute of Oceanology, Academy of Sciences, USSR, p. 89-93.

KULKA, D. W. and J. R. FIRTH. 1987. Observer Program Training Manual - Newfoundland Region. Can. Tech. Rep. Fish. Aquat. Sci., No. 1355 (Revised), 197 p.

MAGNÚSSON, J. V. and J. MAGNÚSSON. 1995. The distribution, relative abundance, and biology of the deepsea fishes of the Icelandic slope and Reykjanes Ridge. In: A.G. Hopper (Editor), Deep-Water Fisheries of the North Atlantic Oceanic Slope, Kluwer Academic Publishers, p. 161-199.

MAUCHLINE, J. and J. D. M. GORDON. 1984. Occurrence and feeding of berycomorphid and percomorphid teleost fish in the Rockall Trough. J. Cons. int. Explor. Mer., 41: 239-247.

MERRETT, N. R. and A. WHEELER. 1983. The correct identification of two trachichthyid fishes (Pisces, Berycomorphi) from the slope fauna west of Britain, with notes on the abundance and commercial importance of Hoplostethus atlanticus. J. Nat. Hist., 17: 569-573.

MOORE, J. A. 2002. Roughies. Family Trachichthyidae. In: Bigelow and Schroeder's Fishes of the Gulf of Maine, B. B. Collette and G. Klein-MacPhee (eds.), Smithsonian Institution Press, p. 302-305.

PECHENIK, L. N. AND F. M. TROYANOVSKII. 1970. Trawling resources on the North-Atlantic continental slope. Main Administration of the Fishing Industry, Northern Basin Northern Fishing Reconnaissance. (Translation: Israel Program for Scientific Translations, Jerusalem, 1971. Available from U.S. Department of Commerce, National Technical Information Service, Springfield, VA 22151).

PAULIN, C. D. 1979. New Zealand roughies (Pisces: Berycomorphi: Trachichthyidae). N.Z. J. Zool., 6: 69-76.

ROSECCHI, E., D. M. TRACEY AND W. R. WEBBER. 1988. Diet of orange roughy Hoplostethus atlanticus (Pisces: Trachichthyidae) on the Challenger Plateau, New Zealand. Mar. Biol., 99: 293-306.

THOMSEN, B. MS 1998. Faroese quest of orange roughy in the North Atlantic. ICES C.M. Doc., No. O:31: 8 p.

VAN GUELPEN, L. 1993. Substantial northward range extension for Gephyroberyx darwini (Berycoidea, Trachichthyidae) in the western North Atlantic, possibly explained by habitat preference. J. Fish Biol., 42: 807810 .

VINNICHENKO, V. I. 1997. Russian investigations and deep water fishery on the Corner Rising seamount in Subarea 6. NAFO Sci. Coun. Studies, 30: 41-49.

WOODS, L. P. and P. M. SONODA. 1973. Order Berycomorphi (Beryciformes). Family Trachichthyidae. In: Fishes of the Western North Atlantic. Memoir Sears Foundation for Marine Research, No. 1, Pt. 6: 293-327.

ZELDIS, J. R., GRIMES, P. J. and J. K. V. INGERSON. 1995. Ascent rates, vertical distribution, and a thermal history model of development of orange roughy, Hoplostethus atlanticus, eggs in the water column. Fish. Bull., Wash., 93: 373-385. 